\title{
Disentangling fast and slow responses of the East Asian summer monsoon to reflecting and absorbing aerosol forcings
}

\author{
Zhili Wang ${ }^{1}$, Lei Lin ${ }^{2}$, Meilin Yang ${ }^{3}$, Yangyang $\mathrm{Xu}^{4}$, and Jiangnan $\mathrm{Li}^{5}$ \\ ${ }^{1}$ State Key Laboratory of Severe Weather and Key Laboratory of Atmospheric Chemistry of CMA, \\ Chinese Academy of Meteorological Sciences, Beijing, 100081, China \\ ${ }^{2}$ School of Atmospheric Sciences and Guangdong Province Key Laboratory for Climate Change and Natural Disaster Studies, \\ Sun Yat-sen University, Zhuhai, 519000, China \\ ${ }^{3}$ Institute of Urban Meteorology, China Meteorological Administration, Beijing, 100089, China \\ ${ }^{4}$ Department of Atmospheric Sciences, Texas A\&M University, College Station, Texas 77843, USA \\ ${ }^{5}$ Canadian Centre for Climate Modelling and Analysis, Science and Technology Branch, Environment Canada, Victoria, \\ V8P5C2, Canada
}

Correspondence to: Lei Lin (linlei3@mail.sysu.edu.cn)

Received: 16 May 2017 - Discussion started: 2 June 2017

Revised: 31 July 2017 - Accepted: 24 August 2017 - Published: 19 September 2017

\begin{abstract}
We examine the roles of fast and slow responses in shaping the total equilibrium response of the East Asian summer monsoon (EASM) to reflecting (sulfate, $\mathrm{SO}_{4}$ ) and absorbing (black carbon, BC) aerosol forcings over the industrial era using the Community Earth System Model version 1 (CESM1). Our results show that there is a clear distinction between fast and slow responses of the EASM to aerosol forcings and the slow climate response due to aerosol-induced change in sea surface temperature (SST) plays an important role in the impacts of aerosols on the EASM. The EASM is weakened by a decrease in land-sea surface thermal contrast in the fast response (FR) component to $\mathrm{SO}_{4}$ forcing, whereas the weakening is more intensive due to the changes in tropospheric thermodynamic and dynamic structures in the slow response (SR) component to $\mathrm{SO}_{4}$. The total climate adjustment caused by $\mathrm{SO}_{4}$ is a significant weakening of the EASM and a decrease in precipitation. The BC-induced fast adjustment strengthens the EASM both by increasing the local land-sea surface thermal contrast and shifting the East Asian subtropical jet (EASJ) northwards. The BC-induced slow climate adjustment, however, weakens the EASM through altering the atmospheric temperature and circulation. Consequently, the EASM is slightly enhanced, especially north of $30^{\circ} \mathrm{N}$, in the total response (TR) to BC. The spatial patterns of precipitation change over East Asia due to $\mathrm{BC}$ are similar in the total response and slow response.
\end{abstract}

This study highlights the importance of ocean response to aerosol forcings in driving the changes of the EASM.

\section{Introduction}

The East Asian summer monsoon (EASM) is one of the most complex and influential monsoon systems over the globe (Ding and Chan, 2005). The activities of about $20 \%$ of world's population would be affected by rainfall change due to the variation of the EASM (Lei et al., 2011). Further understanding of the features of the EASM change has important implications for social economics, agriculture, ecosystem, and water resource management (Hong and Kim, 2011; Auffhammer et al., 2012).

The long-term variation of the EASM is possibly attributed to the influence of various factors, including natural factors (e.g., internal climate variability, volcanic eruptions, and solar variability) and anthropogenic factors (e.g., anthropogenic aerosols and greenhouse gases, GHGs) (Wang et al., 2001, 2015; Li et al., 2010, 2016; Salzmann et al., 2014). Among them, aerosol forcing has been recognized as an important contributor to the long-term change. The analyses based on the Coupled Model Intercomparison Project Phase 5 multi-model simulations indicated that aerosol forcing dominantly contributed to the weakening of the Asian 
summer monsoon during the second half of the 20th century (Salzmann et al., 2014; Song et al., 2014). Other previous studies based on individual climate models also showed that the increases in anthropogenic aerosols could decrease the land-sea surface thermal contrast, thereby leading to a weakening of the EASM (e.g., Liu et al., 2011, 2017; Zhang et al., 2012; Jiang et al., 2013; Wang et al., 2017).

Despite the modeling and observational evidence, there is still debate over whether the total aerosols enhance or weaken the EASM (Guo et al., 2013; Yan et al., 2015), which could be related to the complicated nature of aerosol chemical compositions, an issue we aim to address in this study. Aerosols in the atmosphere consist of optically reflecting and absorbing components. Reflecting aerosols (e.g., sulfate, $\mathrm{SO}_{4}$; and organic carbon) can cool the surface by decreasing the amount of sunlight arriving at the top of the atmosphere (TOA) and surface and cause weak cooling inside the atmosphere due to a weakened solar absorption (Myhre et al., 2013). However, absorbing aerosols (e.g., black carbon, BC; dust; and some components of organic carbon) are able to not only change the radiation budget at the TOA and surface but also directly heat the atmospheric column (Koch and Del Genio, 2010; Huang et al., 2014). Consequently, $\mathrm{BC}$ affects the atmospheric stability, cloud cover, and convection. Therefore, the impact of aerosols on climate derived from modeling studies is likely to be substantially different when various aerosol species are accounted for (Ocko et al., 2014). Using a Goddard Institute for Space Studies model, Menon et al. (2002) suggested that the "wetter-south-dryernorth" phenomenon that has appeared frequently in summer over eastern China during the past decades may be related to the increase in BC emission. However, Zhang et al. (2009) showed responses that are opposite to those in Menon et al. (2002) when considering the integrated effects of carbonaceous aerosols.

Several studies attempted to contrast the $\mathrm{SO}_{4}$ and $\mathrm{BC}$ responses and indicated that scattering and absorbing aerosols would have markedly different effects on regional temperature, atmospheric circulation, and precipitation over East Asia (e.g., Guo et al., 2013; Jiang et al., 2013; Persad et al., 2014). However, these studies all only considered the fast adjustments of atmosphere and land surface to aerosol forcings, without considering the response of oceans. Climate response to a forcing agent can be regarded as a synthesis of fast and slow responses (Andrews et al., 2010; Ganguly et al., 2012). The response to direct effects of aerosols on radiation, cloud, atmospheric heating rate, and land surface is treated as the fast response, while the response to change in global surface temperature, especially sea surface temperature (SST), caused by the aerosol forcing is identified as the slow response (SR). The latter can have a more important effect on the climate system (Allen and Sherwood, 2010; Ganguly et al., 2012; Xu and Xie, 2015; Voigt et al., 2017). A general circulation model study by Hsieh et al. (2013) showed that aerosols could lead to different spatial responses of climate over the global scale when using an interactive ocean model as opposed to fixed SST as the ocean boundary conditions. Ganguly et al. (2012) also indicated that the slow component played a more critical role in shaping the total equilibrium response of the South Asian summer monsoon to aerosol forcing.

The East Asian monsoon is considered as a more complex monsoon system. What role does the feedback of oceans to aerosol forcings play in driving the changes of the EASM? This study explores the roles of fast and slow responses in forming the total equilibrium response of the EASM to both reflecting and absorbing aerosol forcings over the industrial era using a state-of-the-art Earth system model. We take $\mathrm{SO}_{4}$ and $\mathrm{BC}$ as the representatives of reflecting and absorbing aerosols separately. To our knowledge, no previous study has partitioned the fast and slow responses of the East Asian monsoon to various aerosol species using a fully coupled climate model.

The paper is organized as follows. The model and simulations performed are described in Sect. 2. The total, fast, and slow responses of the EASM to various aerosol forcings are presented in Sect. 3. Our discussion and conclusions are summarized in Sect. 4. We primarily focus on the variation of the EASM over the region $20-40^{\circ} \mathrm{N}, 100-140^{\circ} \mathrm{E}$. The summer includes the months of June, July, and August (JJA).

\section{Method}

\subsection{Global climate model}

We used the Community Earth System Model version 1 (CESM1), a fully coupled ocean-atmosphere-land-sea-ice model, created by the National Center for Atmospheric Research of the US (Hurrell et al., 2013). The model is a version with a finite-volume approximation $1^{\circ}$ horizontal resolution (latitude $0.9^{\circ} \times$ longitude $1.25^{\circ}$ for the atmosphere and land, and $1^{\circ} \times 1^{\circ}$ for the ocean) and 30-level vertical resolution, with a rigid lid at $4 \mathrm{hPa}$. CESM1 includes the primary anthropogenic forcing agents, such as GHGs, tropospheric and stratospheric ozone, sulfate, and black and primary organic carbon. The three-mode modal aerosol model that contains the Aitken, accumulation, and coarse modes has been implemented in the model (Liu et al., 2012). It can provide the number and mass concentrations of internally mixed aerosols for the three modes. The model also includes the physical representations of aerosol direct, semi-direct, and indirect effects for both liquid- and ice-phase clouds (Morrison and Gettelman, 2008; Gettelman et al., 2010; Ghan et al., 2012).

Anthropogenic and biomass burning emissions of aerosols and their precursors are based on Lamarque et al. (2010). However, the $\mathrm{BC}$ emission at the present day is adjusted due to the potential underestimation of $\mathrm{BC}$ heating in the atmosphere in CESM1 (Xu et al., 2013; Xu and Xie, 2015). BC emissions over East Asia and South Asia are increased by a 
Table 1. Simulation setups.

\begin{tabular}{llll}
\hline Simulation & Aerosol emissions & Ocean & Ensembles \\
\hline PI & Year $1850 \mathrm{SO}_{2}$ and BC & Dynamic ocean model & 1 \\
$\mathrm{PDSO}_{4}$ & Year $2000 \mathrm{SO}_{2}$ and $1850 \mathrm{BC}$ & Dynamic ocean model & 1 \\
$\mathrm{PDBC}_{\mathrm{PI} F S S T}$ & Year $1850 \mathrm{SO}_{2}$ and 2000 BC & Dynamic ocean model & 5 \\
$\mathrm{PDSO}_{4}$ FSST & Year 1850 $\mathrm{SO}_{2}$ and BC & Fixed SST from PI & 1 \\
PDBC_FSST Yeo0 $\mathrm{SO}_{2}$ and 1850 BC & Fixed SST from PI & 1 \\
\hline
\end{tabular}

factor of 2 and 4, respectively. The emissions are changed in all economic sectors (industrial, energy, etc.) and all seasons by the same ratio. Such an adjustment significantly improved the simulated radiative forcing compared to the direct observations.

\subsection{Simulations}

This study used a series of simulations (Table 1):

- Fully Coupled CESM1 simulations. The control case was a 394-year preindustrial simulation (referred to as $\mathrm{PI})$. Two perturbed simulations, sulfur dioxide $\left(\mathrm{SO}_{2}\right)$ (a precursor of $\mathrm{SO}_{4}$ ) and $\mathrm{BC}$ emissions, were increased instantaneously from preindustrial to present-day (PD) levels, but the GHG concentrations were unchanged (referred to as $\mathrm{PDSO}_{4}$ and PDBC). Starting from the end of the 319th year, the perturbed simulations were run for 75 years, with the last 60 years being analyzed. To increase the signal-to-noise ratio caused by $\mathrm{BC}$ forcing (a smaller forcing), we performed an ensemble of five perturbed simulations by altering the atmospheric initial conditions by an air temperature difference at roundoff level (order of $10^{-14}{ }^{\circ} \mathrm{C}$ ). The long averaging time (394 years for the PI case, 60 years in the $\mathrm{SO}_{4}$-perturbed simulations, and $60 \times 5$ years in the BC-perturbed simulations) can restrain the impact of decadal natural climate variability and obtain a clear effect due to aerosol forcings.

- Atmosphere-only model simulations with fixed SST. The model settings were same as those in the coupled simulations, but the SST was always fixed at the preindustrial level, with only seasonal variability. The SST data are from the outputs of the PI-coupled simulation. Three simulations were performed - using the preindustrial aerosol emissions (referred to as PI_FSST), presentday $\mathrm{SO}_{2}$ emission (referred to as $\mathrm{PDSO}_{4}$ FSST), and present-day BC emission (referred to as PDBC_FSST), respectively. Each simulation was run for 75 years, with the last 60 years being analyzed. These three atmosphere-only simulations were also used to calculate the effective radiative forcings (ERFs) of $\mathrm{SO}_{4}$ and $\mathrm{BC}$ at the present day following Myhre et al. (2013).
Those sets of simulations mentioned above have been adopted to examine the responses of the tropospheric atmosphere (Xu and Xie, 2015), mountain snow cover (Xu et al., 2016), and terrestrial aridity (Lin et al., 2016) to various forcing agents. The total response (TR) of the EASM to $\mathrm{SO}_{4}$ or $\mathrm{BC}$ forcing was defined as the difference between $\mathrm{PDSO}_{4}$ or PDBC and PI:

$\mathrm{TRSO}_{4}=\mathrm{PDSO}_{4}-\mathrm{PI}$,

$\mathrm{TRBC}=\mathrm{PDBC}-\mathrm{PI}$.

The fast response (FR) of the EASM to $\mathrm{SO}_{4}$ or $\mathrm{BC}$ forcing was expressed as the difference between $\mathrm{PDSO}_{4}$ FSST or PDBC_FSST and PI_FSST:

$$
\begin{aligned}
& \mathrm{FRSO}_{4}=\mathrm{PDSO}_{4} \_F S S T-\text { PI_FSST } \\
& \mathrm{FRBC}=\mathrm{PDBC} \_F S S T-\text { PI_FSST. }
\end{aligned}
$$

Note that the slow response of the EASM to aerosol forcing, defined as the climate response to aerosol-induced SST change, was calculated by subtracting the FR from the TR (Andrews et al., 2010; Ganguly et al., 2012; Samset et al., 2016) rather than by performing the simulations with the perturbed SST pattern caused by aerosol forcing:

$\mathrm{SR}=\mathrm{TR}-\mathrm{FR}$

Hsieh et al. (2013) and Xu and Xie (2015) indicated that this approximate method was a legitimate metric to obtain the slow response of climate to aerosol forcing.

\section{Results}

\subsection{Aerosol ERFs and their induced SST responses}

Figure 1 shows the changes in aerosol optical depths (AODs) at $550 \mathrm{~nm}$ from PI to PD induced by $\mathrm{SO}_{4}$ and $\mathrm{BC}$. The AOD increases significantly over most of the globe except for some oceans due to the increase in anthropogenic aerosol loading. The change in AOD induced by $\mathrm{SO}_{4}$ is larger than that induced by BC. The prominent increase in AOD caused by $\mathrm{SO}_{4}$ appears over eastern China, the USA, India, and western Europe, while the AOD decreases over the tropical and subtropical oceans of the Southern Hemisphere (SH). The 
(a) $\mathrm{SO}_{4}$-induced $\mathrm{AOD}$ change

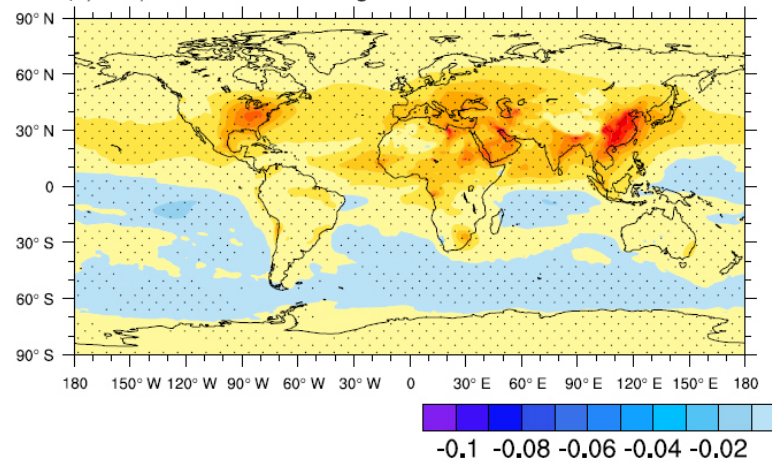

(b) BC-induced AOD Change

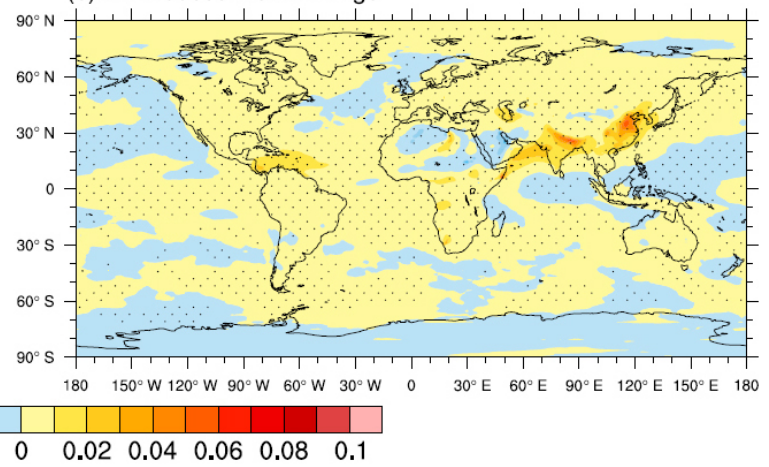

Figure 1. Annual mean distributions of changes in aerosol optical depths at $550 \mathrm{~nm}$ from PI to PD induced by (a) $\mathrm{SO}_{4}$ and (b) $\mathrm{BC}$. The dots represent significance at $\geq 95 \%$ confidence level from the $t$ test.

change in BC leads to a large increase in AOD over eastern China and South Asia but a slight reduction over the tropical Pacific and Indian Ocean of the Northern Hemisphere (NH), northern Atlantic, and high latitudes of the SH.

The fifth assessment report of the Intergovernmental Panel on Climate Change provided a new definition of radiative forcing named ERF, which is a better indicator of the climate responses (Myhre et al., 2013). The global distributions of simulated $\mathrm{SO}_{4}$ and BC ERFs at the TOA are shown in Fig. 2. The ERFs are calculated using the atmosphere-only model simulations with fixed SST by subtracting the net radiative flux at the TOA. There are fundamental differences between both aerosol ERFs. Reflecting $\mathrm{SO}_{4}$ gives rise to large negative ERFs, especially in East and Southeast Asia, Central Africa, western Europe, and the subtropical oceans. However, absorbing BC leads to marked positive ERFs over East and South Asia and Central Africa, where the BC emission is large. The simulated global annual mean $\mathrm{SO}_{4}$ and $\mathrm{BC}$ ERFs are -0.98 and $+0.36 \mathrm{~W} \mathrm{~m}^{-2}$, respectively. The simulated $\mathrm{SO}_{4}$ forcing is close to those estimated by Zelinka et al. (2014) and Forster et al. (2016), while our results show a larger BC forcing. This is attributed to the correction of BC emission in our simulations (Xu et al., 2013). The difference between reflecting and absorbing aerosol forcings implies the substantially different climate responses.

Aerosol-induced SST change is an important part of the climatic effect of aerosols (Xu and Xie, 2015). Figure 3 shows the changes in SST caused by various aerosol species from the fully coupled simulations. Despite the essential difference between both types of forcings, the spatial pattern of SST change caused by $\mathrm{SO}_{4}$ is found to be similar to that caused by BC (opposite in sign). It is characterized by a large SST change over the mid- and high-latitude oceans of the $\mathrm{NH}$ but only a slight SST change in the $\mathrm{SH}$. The $\mathrm{SO}_{4}$ forcing leads to a significant decrease in SST over the northern Pacific, northwestern Atlantic, and NH high-latitude oceans, with the largest cooling exceeding $1.5 \mathrm{~K}$. However, the opposite occurs over those regions in response to $\mathrm{BC}$, with the
Table 2. Simulated changes in annual and JJA mean sea surface temperatures caused by $\mathrm{SO}_{4}$ and $\mathrm{BC}$ averaged over globe, Northern Hemisphere (NH), and Southern Hemisphere ( $\mathrm{SH}$; unit: $\mathrm{K})$.

\begin{tabular}{lrrr}
\hline & Globe & $\mathrm{NH}$ & $\mathrm{SH}$ \\
\hline $\mathrm{SO}_{4}$ & $-0.44 /-0.42$ & $-0.7 /-0.64$ & $-0.24 /-0.26$ \\
$\mathrm{BC}$ & $0.12 / 0.11$ & $0.17 / 0.16$ & $0.07 / 0.08$ \\
\hline
\end{tabular}

largest warming reaching $1 \mathrm{~K}$. A unique characteristic of the SST response to BC is the obvious warming over the Indian Ocean-western Pacific warm pool. Similar patterns in SST changes were found by Chung and Seinfeld (2005), Friedman et al. (2013), and Ocko et al. (2014). However, Ocko et al. (2014) showed a weaker SST change in the NH high latitudes induced by $\mathrm{SO}_{4}$ or $\mathrm{BC}$ and a warming in the $\mathrm{SH}$ high latitudes caused by $\mathrm{SO}_{4}$, which was not seen in other studies. The simulated global annual mean SST changes caused by $\mathrm{SO}_{4}$ and $\mathrm{BC}$ are $-0.44 \mathrm{~K}(\mathrm{NH}:-0.7 \mathrm{~K}, \mathrm{SH}:-0.24 \mathrm{~K})$ and $+0.12 \mathrm{~K}(\mathrm{NH}:+0.17 \mathrm{~K}, \mathrm{SH}:+0.07 \mathrm{~K})$, respectively (Table 2). Such an interhemispheric asymmetric adjustment in SST has been used as a crucial index of climate change (Ocko et al., 2014).

\subsection{Response of the EASM to $\mathrm{SO}_{4}$ forcing}

The sign of the change in surface temperature is consistent with that of the forcing. Negative $\mathrm{SO}_{4}$ forcing leads to a marked surface cooling in summer over the East Asian monsoon region (EAMR), which increases with latitude (Fig. 4a). In particular, the cooling exceeds $1 \mathrm{~K}$ over most of the NH subtropical oceans. The anomalous northerly winds prevail over eastern China and the surrounding oceans between 20 and $40^{\circ} \mathrm{N}$ due to $\mathrm{SO}_{4}$ forcing (Fig. 4d), which signifies the weakening of the EASM circulation. As seen in Fig. 4, the slow responses of surface air temperature and winds at $850 \mathrm{hPa}$ to $\mathrm{SO}_{4}$-induced SST change closely resemble their total responses to $\mathrm{SO}_{4}$. 


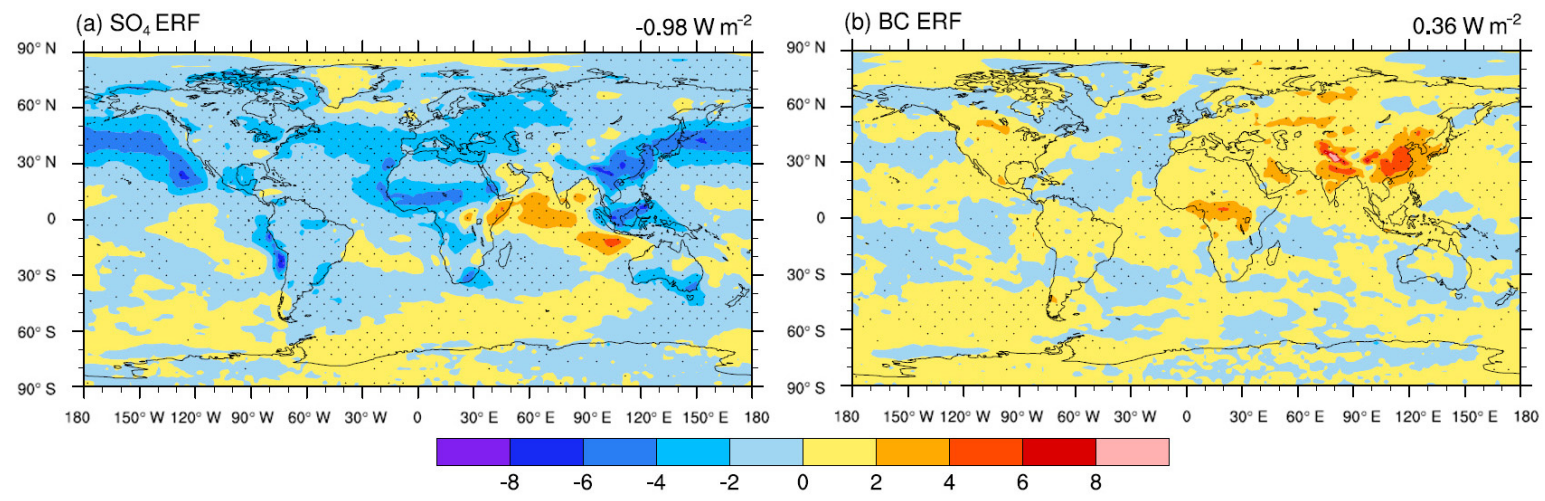

Figure 2. Annual mean distributions of (a) $\mathrm{SO}_{4}$ and (b) BC ERF from PI to PD (unit: $\mathrm{W} \mathrm{m}^{-2}$ ). ERF is defined as the perturbation of net radiative flux at the TOA caused by aerosols. The dots represent significance at $\geq 95 \%$ confidence level from the $t$ test.

(a) $\mathrm{SO}_{4}$-induced SST perturbation

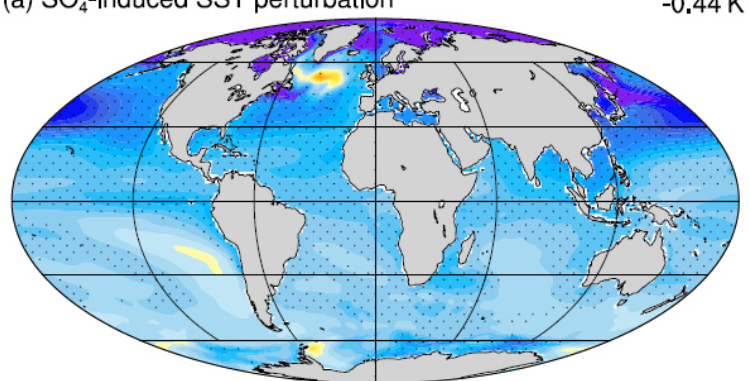

(b) BC-induced SST perturbation

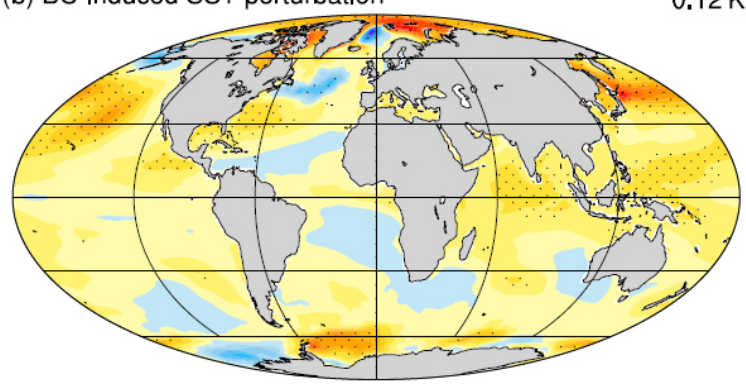

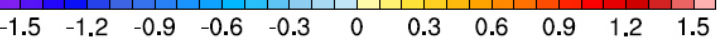

Figure 3. Annual mean distributions of SST responses to (a) $\mathrm{SO}_{4}$ and (b) $\mathrm{BC}$ forcings (unit: $\mathrm{K}$ ). The dots represent significance at $\geq 95 \%$ confidence level from the $t$ test.

The fast response of surface air temperature to $\mathrm{SO}_{4}$ forcing primarily features a cooling over continental East Asia, with the values being less than $-0.3 \mathrm{~K}$ over most of continental East Asia (Fig. 4b), because the SST is fixed in these simulations and changes in $\mathrm{SO}_{2}$ emissions are concentrated over land. Such a change in surface temperature decreases the land-sea surface thermal contrast over the EAMR, thus weakening the EASM circulation (Fig. 4e). This is consistent with previous studies using other general circulation models with fixed SST (e.g., Jiang et al., 2013; Dong et al., 2016). However, note that the weakening of the EASM in the fast response to $\mathrm{SO}_{4}$ is too weak to explain the total response of the EASM to $\mathrm{SO}_{4}$, especially over eastern China (Fig. 4d and e). Therefore, we next elaborate the physical mechanism behind the slow response of the EASM to $\mathrm{SO}_{4}$.

Figure 5 shows the JJA mean responses of zonally averaged atmospheric temperature between 100 and $140^{\circ} \mathrm{E}$ to $\mathrm{SO}_{4}$ forcing over the EAMR. The $\mathrm{SO}_{4}$-induced slow climate response leads to a significant cooling in the whole troposphere (Fig. 5c), though $\mathrm{SO}_{4}$ does not largely affect the radiation in the atmosphere. It is responsible for a large fraction of the atmospheric cooling in the total response to $\mathrm{SO}_{4}$
(Fig. 5a and c). This is because the prominent decrease in the JJA mean SST caused by $\mathrm{SO}_{4}$ also occurs in the NH midlatitude oceans, with the values being less than $-1 \mathrm{~K}$ over most of the northern Pacific and northwestern Atlantic (Fig. S1a in the Supplement). The interhemispheric asymmetric change in SST may distinctly affect the free troposphere by alerting the tropical circulations and midlatitude eddies (Ming et al., 2011; Hsieh et al., 2013; Ocko et al., 2014; Xu and $\mathrm{Xie}, 2015)$. The most remarkable feature of change in atmospheric temperature in the slow response to $\mathrm{SO}_{4}$ is a deep tropospheric cooling between 30 and $45^{\circ} \mathrm{N}$ (Fig. 5c). A similar temperature response to aerosol forcings was found by Rotstayn et al. (2014) based on the multi-model ensemble simulations, which indicates that this is a robust feature of climate response to aerosols. There is an anomalous cooling center in the upper troposphere $(200-500 \mathrm{hPa})$, with the cooling exceeding $1 \mathrm{~K}$ (Fig. 5c), which leads to a prominent decrease in geopotential height at those altitudes (Fig. 5f). The geopotential height at about $200 \mathrm{hPa}$ is reduced by more than $35 \mathrm{~m}$.

The East Asian subtropical jet (EASJ) that is located around $40^{\circ} \mathrm{N}$ at $200 \mathrm{hPa}$ is an important component of the 


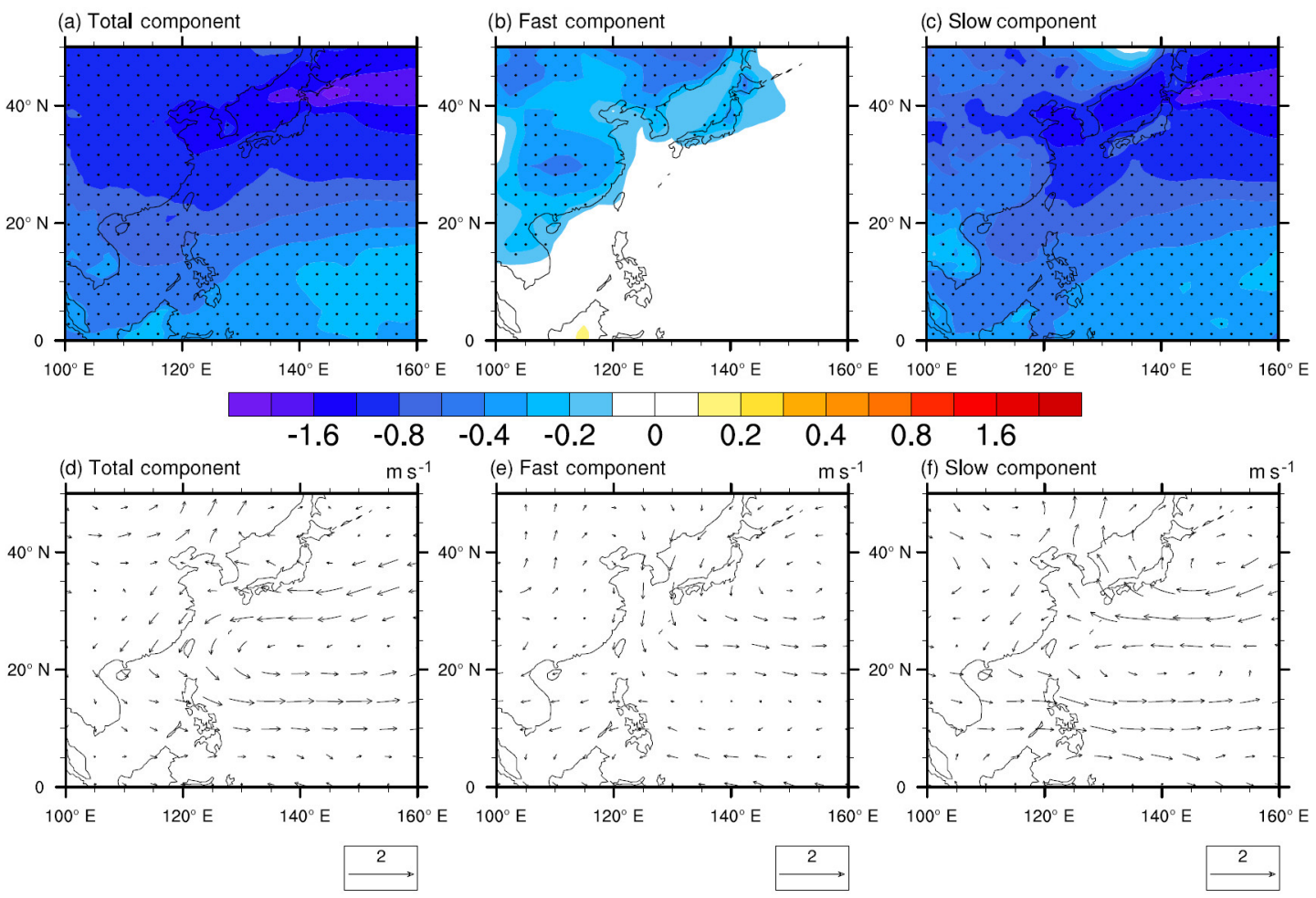

Figure 4. JJA mean total, fast, and slow responses of (a, b, c) surface air temperature (unit: $\mathrm{K}$ ) and (d, e, f) wind vectors at $850 \mathrm{hPa}$ (unit: $\mathrm{m} \mathrm{s}^{-1}$ ) to $\mathrm{SO}_{4}$ forcing. The dots represent significance at $\geq 95 \%$ confidence level from the $t$ test.

East Asian monsoon. The change in geopotential height in the slow response to $\mathrm{SO}_{4}$ increases the poleward (equatorward) pressure gradient force to the south (north) of the cooling center region. Such a change in pressure gradient force leads to an increase (decrease) in westerlies to the south (north) of the EASJ center through the geostrophic balance between the Coriolis force and pressure gradient force (Yu et al., 2004). It is shown in Fig. 6a that the largest increase and decrease of more than $\pm 1 \mathrm{~m} \mathrm{~s}^{-1}$ in westerlies occur at about 25 and $45^{\circ} \mathrm{N}$, respectively. Consequently, the EASJ shifts southwards in response to $\mathrm{SO}_{4}$. The slow response dominates over the total response of the EASJ to $\mathrm{SO}_{4}$ (Fig. 6).

The north and south flanks of the jet axis correspond generally to the divergence and convergence areas in the lower atmosphere, respectively. The southward displacement of the EASJ center implies the southward spread of divergence areas, thereby resulting in an anomalous surface anticyclone over continental East Asia between 30 and $40^{\circ} \mathrm{N}$. The anomalous subsidence motion in the lower atmosphere around $40^{\circ} \mathrm{N}$ (Fig. S2c) due to the large surface cooling also intensifies the anomalous surface anticyclone. To the east of the anticyclonic center, anomalous northerlies increase prominently (Fig. 4f). In addition, the interhemispheric SST gradient caused by $\mathrm{SO}_{4}$ (Fig. S1a) strengthens the ascending branch of the local Hadley cell between 20 and $35^{\circ} \mathrm{N}$ in the summer (Figs. S2c and S3c), thereby resulting in an anomalous cyclonic vortex over southeastern China and the western Pacific (Fig. 4f). To the west of the cyclonic center, anomalous northerly winds are further increased. Finally, the $\mathrm{SO}_{4}$-induced slow climate response leads to a more intense weakening of the EASM circulation than its fast response. Dai et al. (2013) also suggested that the thermal contrast in the mid-upper troposphere played a more important role than that in the mid-lower troposphere in impacting the strength and variations of the Asian summer monsoon circulations. Drop in tropopause height over the EAMR can suppress the convection and weaken the EASM. As seen in Fig. 7a, the tropopause north of $40^{\circ} \mathrm{N}$ in the summer declines significantly in the total response to $\mathrm{SO}_{4}$, which primarily contributed by its slow response. The sharp drop also coincides with the southward displacement of the $\mathrm{NH}$ subtropical jet, as the jet approximately divides the tropics (with higher tropopause) and extratropics (Ming et al., 2011). The above analyses indicate the importance of ocean response to $\mathrm{SO}_{4}$ forcing in driving the changes of the EASM circulation.

Note that the changes in atmospheric temperature and geopotential height due to the adjustments in clouds and atmospheric states in the fast response to $\mathrm{SO}_{4}$ (Fig. $5 \mathrm{~b}$ and e) lead to the increase of more than $0.8 \mathrm{~m} \mathrm{~s}^{-1}$ in westerlies at the north of the jet center (Fig. 6b). The positive change of westerlies in the fast response is comparable to the negative change of westerlies in the slow response to $\mathrm{SO}_{4}$ due to the 

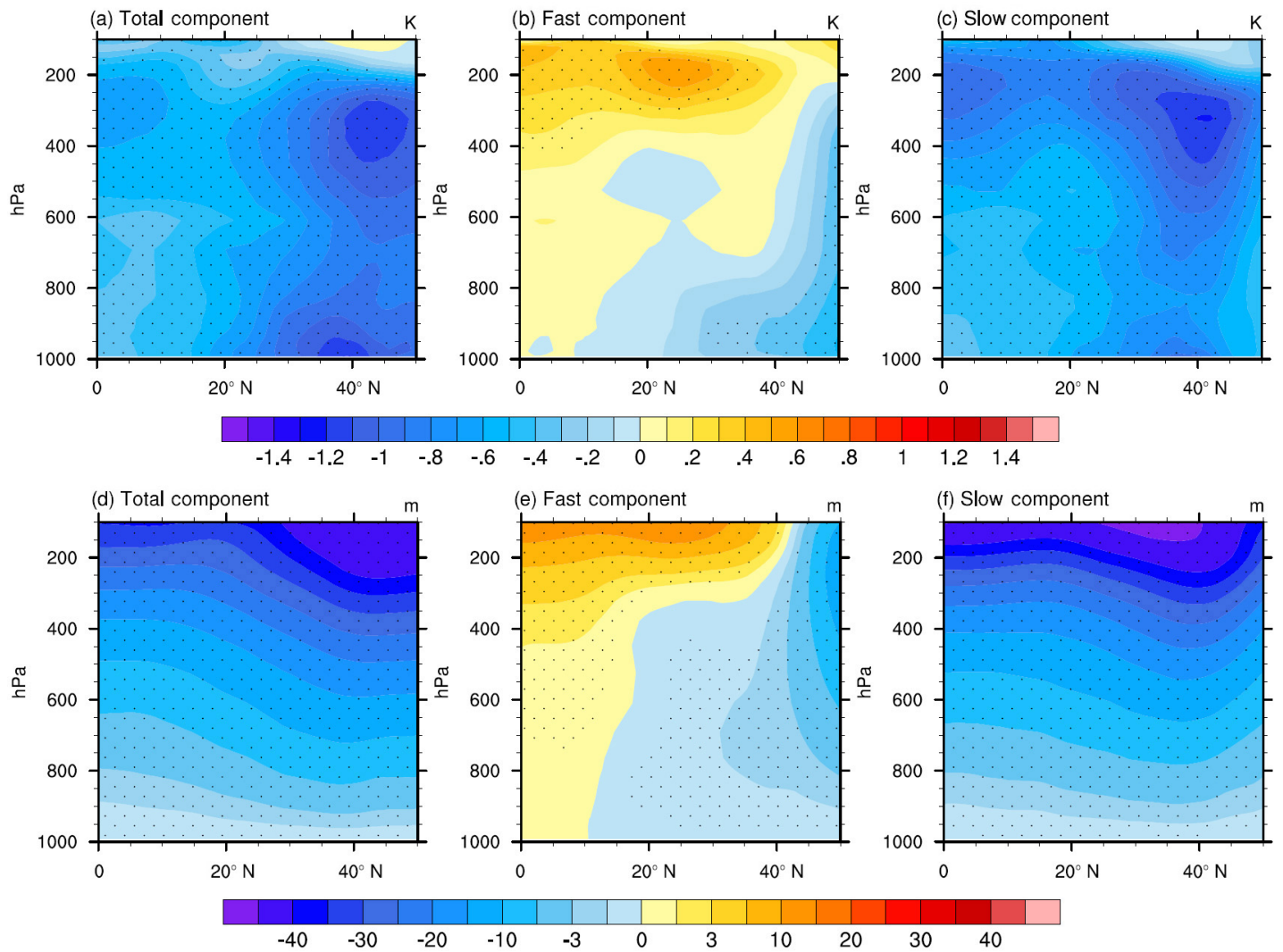

Figure 5. JJA mean total, fast, and slow responses of zonally averaged $(\mathbf{a}, \mathbf{b}, \mathbf{c})$ atmospheric temperature (unit: K) and (d, e, f) geopotential height (unit: $\mathrm{m}$ ) between 100 and $140^{\circ} \mathrm{E}$ to $\mathrm{SO}_{4}$ forcing. The dots represent significance at $\geq 95 \%$ confidence level from the $t$ test.
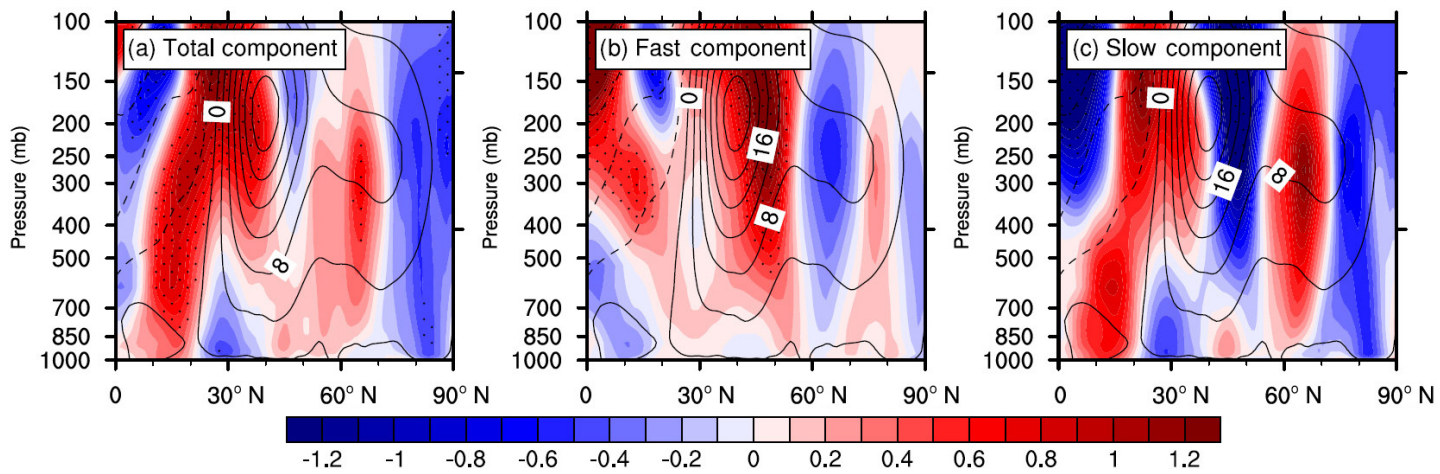

Figure 6. JJA mean total, fast, and slow responses of zonally averaged zonal wind between 100 and $140^{\circ} \mathrm{E}_{\text {to }} \mathrm{SO}_{4}$ forcing (unit: $\mathrm{m} \mathrm{s}^{-1}$ ). The dashed and solid lines represent the climatological JJA mean easterly and westerly winds in PI, respectively. The dots represent significance at $\geq 95 \%$ confidence level from the $t$ test.

comparable changes in temperature and geopotential height. The change of the jet in the fast response to $\mathrm{SO}_{4}$ (Fig. 6b) is conducive to the enhancement of the EASM, which partially offsets the weakening of the EASM due to the decrease of the land-sea surface thermal contrast.

The weakening of the EASM circulation caused by $\mathrm{SO}_{4}$ forcing suppresses the transport of surface warm and moist air northwards and upwards, which results in a significant de- crease in precipitation over eastern and southern China and the ambient oceans (Fig. 8a). In particular, the precipitation is decreased by more than $0.6 \mathrm{~mm}_{\text {day }}{ }^{-1}$ over most of southern China. The cooling in the lower troposphere and warming in the upper troposphere due to the fast response north of $20^{\circ} \mathrm{N}$ (Fig. 5b) can suppress the vertical ascending motion (Fig. S2b) and moisture transfer, thereby also contributing to the decrease in precipitation. However, the precipitation 

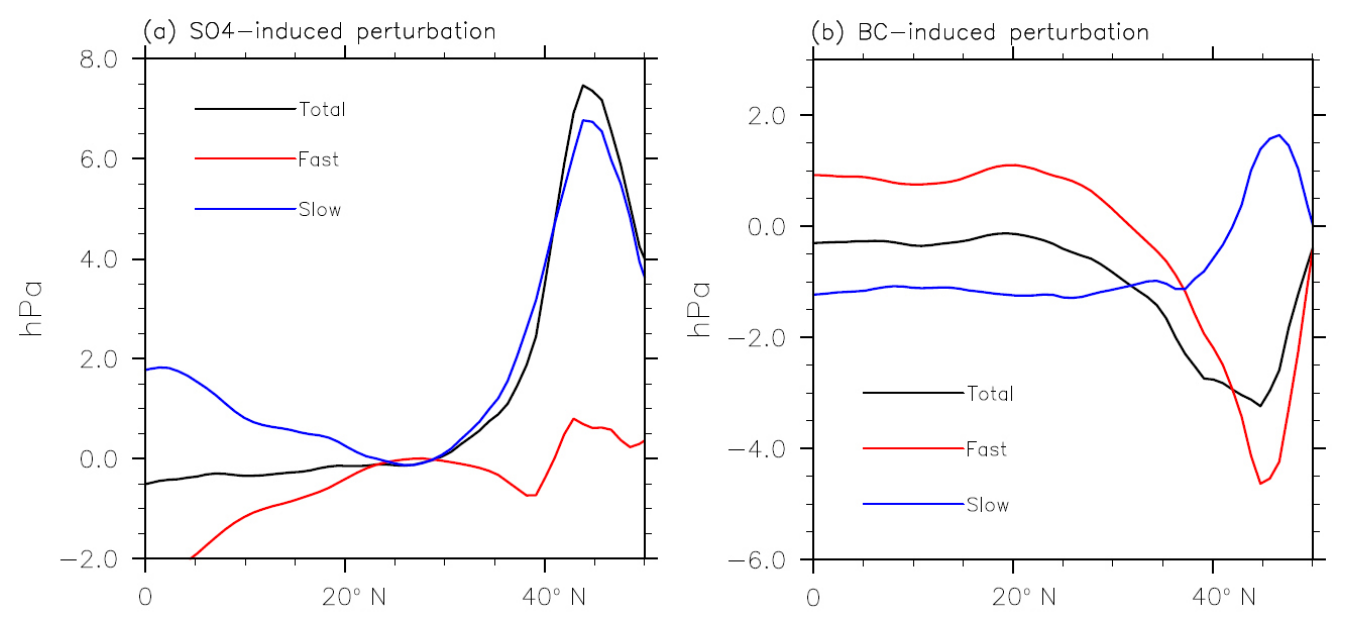

Figure 7. JJA mean total, fast, and slow responses of zonally averaged tropopause heights between 100 and $120^{\circ} \mathrm{E}$ to (a) $\mathrm{SO}_{4}$ and (b) $\mathrm{BC}$ forcing (unit: $\mathrm{hPa}$ ). The positive values indicate a drop in the tropopause.

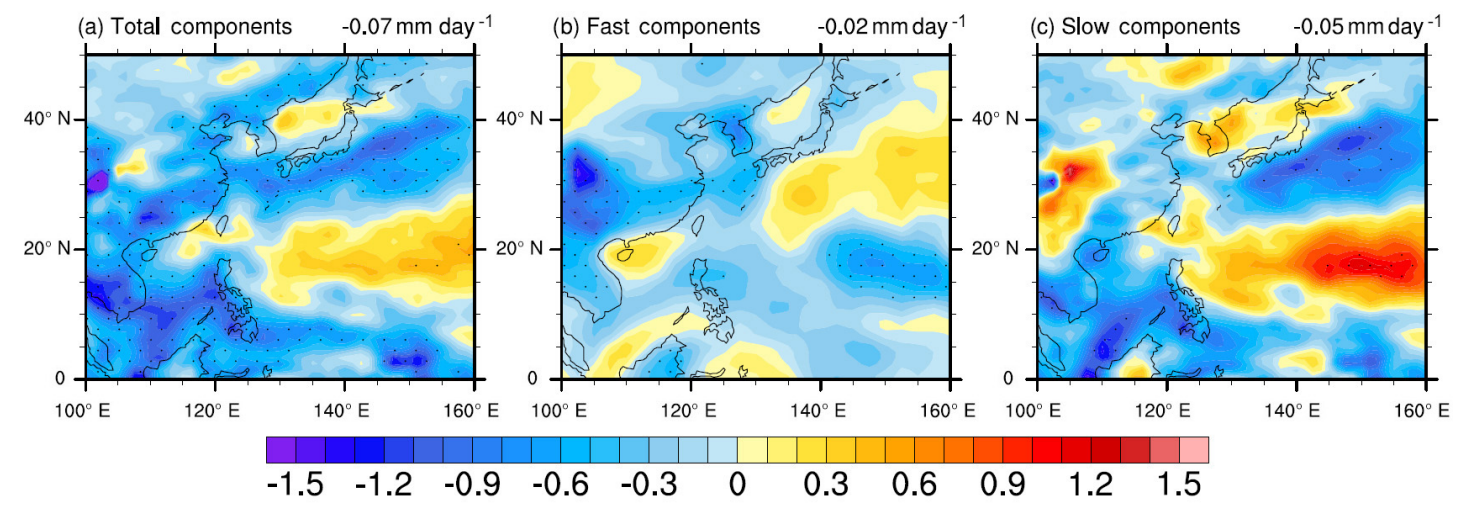

Figure 8. JJA mean total, fast, and slow responses of precipitation rate to $\mathrm{SO}_{4}$ forcing (unit: $\mathrm{mm} \mathrm{day}^{-1}$ ). The values in the top right corner of the figures represent the responses averaged over the region $0-50^{\circ} \mathrm{N}, 100-140^{\circ} \mathrm{E}$. The dots represent significance at $\geq 95 \%$ confidence level from the $t$ test.

increases (yet not significantly) over some of the western Pacific due to the enhanced convection in the slow response to $\mathrm{SO}_{4}$ (Fig. S2c), with the maximum exceeding $1 \mathrm{~mm}^{\text {day }}{ }^{-1}$. Note that the $\mathrm{SO}_{4}$-induced slow climate response leads to a large increase in precipitation over western China, which is the opposite compared to its fast response (Fig. 8b and c). This is because the enhanced easterly anomalies in the lower troposphere between 25 and $35^{\circ} \mathrm{N}$ in the slow response (Fig. $4 \mathrm{f}$ and $6 \mathrm{c}$ ) bring about more moisture into the inland regions of China, which is beneficial to the formation of clouds and precipitation. In a word, the decrease in precipitation over land in East Asia in the total response to $\mathrm{SO}_{4}$ is dominated by the fast response, while the change in precipitation over the adjacent ocean is dominated by the slow response.

\subsection{Response of the EASM to BC forcing}

Figure 9 shows JJA mean responses of surface air temperature and wind vectors at $850 \mathrm{hPa}$ to $\mathrm{BC}$ forcing. Absorbing
$\mathrm{BC}$ increases the surface air temperature over the EAMR, with the largest warming appearing at the $\mathrm{NH}$ midlatitudes, especially over the northwestern Pacific, with the maximum exceeding $0.8 \mathrm{~K}$ (Fig. 9a). This is mainly from the contribution of the slow climate response to BC (Fig. 9c). The small anomalous southerly winds at $850 \mathrm{hPa}$ prevail and the EASM circulation is slightly enhanced, especially north of $30^{\circ} \mathrm{N}$, in the total climate response to BC (Fig. 9d), which is mainly attributed to their fast responses to $\mathrm{BC}$. The fast and slow responses of surface winds to BC over the EAMR are inverses of each other. The anomalous northerlies in the slow response that tend to weaken the EASM greatly offset the anomalous southerlies in the fast response to BC (Fig. 9e and f).

Now we explain why the enhancement of the monsoon in the fast response to $\mathrm{BC}$ forcing is strong. Firstly, the large surface warming in the fast response to $\mathrm{BC}$ occurs over continental East Asia, especially north of $30^{\circ} \mathrm{N}$, with the warming exceeding $0.2 \mathrm{~K}$ (Fig. 9b). This increases the land-sea surface thermal contrast over the EAMR, thereby enhancing 


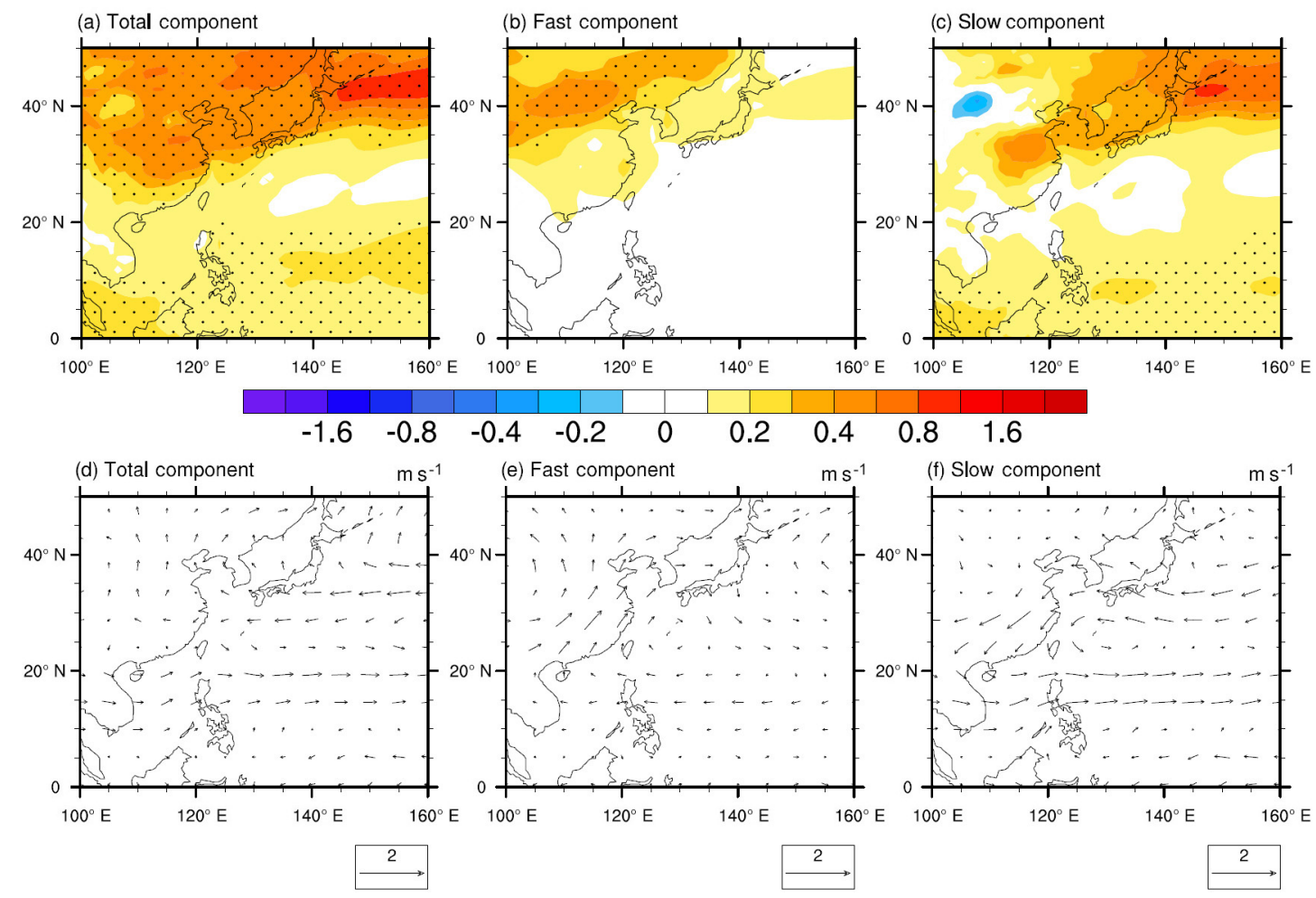

Figure 9. JJA mean total, fast, and slow responses of (a, b, c) surface air temperature (unit: K) and (d, e, f) wind vectors at $850 \mathrm{hPa}($ unit: $\mathrm{m} \mathrm{s}^{-1}$ ) to BC forcing. The dots represent significance at $\geq 95 \%$ confidence level from the $t$ test.

the EASM circulation (Fig. 9e). This mechanism is also at work in the fast response to $\mathrm{SO}_{4}$. Secondly and unique to the $\mathrm{BC}$ case, the direct absorption of solar radiation by $\mathrm{BC}$ leads to a deep tropospheric warming of 0.2 to $1 \mathrm{~K}$ at the $\mathrm{NH}$ midlatitudes (Fig. 10), which dominates over the tropospheric warming in the total response to BC. An anomalous warming center of more than $0.6 \mathrm{~K}$ appears and the geopotential height is increased by more than $10 \mathrm{~m}$ in the upper troposphere around $40^{\circ} \mathrm{N}$ (Fig. 10e). Consequently, the pressure increases in the uppermost troposphere, which strengthens the poleward (equatorward) pressure gradient force in the north (south) flank of the warming region. This results in an increase of 0.2 to $1 \mathrm{~m} \mathrm{~s}^{-1}$ (a decrease of 0.8 to $1.2 \mathrm{~m} \mathrm{~s}^{-1}$ ) in westerly winds in the north (south) flank of the EASJ center and the northward movement of the EASJ (Fig. 11b). The total response of the jet is consistent with the fast response of it to BC. With the change of the EASJ, an anomalous cyclonic vortex is formed over land in East Asia and anomalous southerly winds increase over eastern China. This second mechanism involving the EASJ change further magnifies the enhancement of the EASM caused by the increase in land-sea surface thermal contrast in the fast response to BC. The elevation of the tropopause between 40 and $50^{\circ} \mathrm{N}$ in the summer due to the fast response also implies the strengthening of the EASM (Fig. 7b). The fast response dominates over the total response of tropopause height to BC.
The BC-induced slow response is in the opposite direction of the fast response. Like the annual mean SST response, the significant increase in the JJA mean SST caused by BC occurs not only in the $\mathrm{NH}$ midlatitude oceans but also in the Indian Ocean-western Pacific warm pool, with the warming exceeding $0.2 \mathrm{~K}$ over most areas (Fig. S1b). This results in the deep tropospheric warming north of $40^{\circ} \mathrm{N}$ and a larger warming in the upper troposphere between 20 and $30^{\circ} \mathrm{N}$, respectively (Fig. 10c). Keshavamurty (1982) found that the warming over tropical western Pacific could significantly enhance the convection motion in the western Pacific and that it was more efficient in producing atmospheric circulation anomalies. Therefore, the $\mathrm{BC}$-induced slow climate response also strengthens the ascending branch of the local Hadley cell between 15 and $30^{\circ} \mathrm{N}$ in the summer (Figs. S4c and S5c). This leads to an anomalous cyclone in the lower atmosphere over these regions, thus increasing the anomalous northerly winds over eastern China (Fig. 9f). While the tropospheric temperature increases in the slow response to $\mathrm{BC}$, the warming in the upper troposphere of around $40^{\circ} \mathrm{N}$ is less than that on both of its flanks (Fig. 10c). Such an adjustment in tropospheric temperature is conducive to a southward shifting of the EASJ (Fig. 11c). These EASJ changes cause the $\mathrm{BC}$-induced slow response to weaken the EASM circulation, which even overcomes the strengthening of the EASM due to the increase in land-sea surface thermal contrast in the slow 


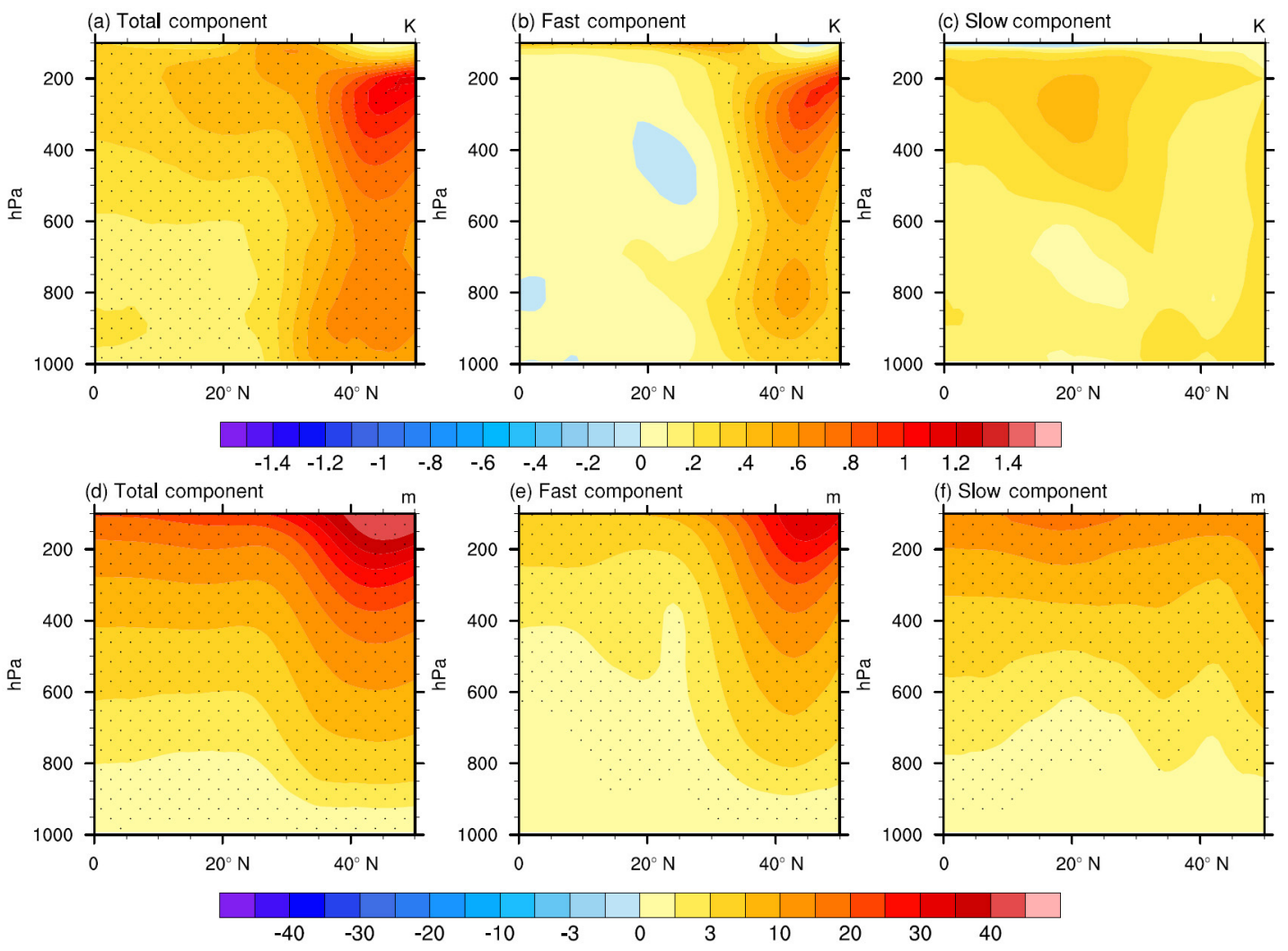

Figure 10. JJA mean total, fast, and slow responses of zonally averaged (a, b, c) atmospheric temperature (unit: K) and (d, e, f) geopotential height (unit: $\mathrm{m}$ ) between 100 and $140^{\circ} \mathrm{E}$ to $\mathrm{BC}$ forcing. The dots represent significance at $\geq 95 \%$ confidence level from the $t$ test.

response (Fig. 9c). The opposite fast and slow responses of tropopause height to $\mathrm{BC}$ also indicate their adverse impact on the EASM circulation (Fig. 7b).

Lastly, the JJA mean response of precipitation to BC forcing over the EAMR is weaker than that found in the response to $\mathrm{SO}_{4}$ with less area in which the change is significant (Fig. 12), mainly because of a smaller radiative forcing. The total response of precipitation to $\mathrm{BC}$ manifests a spatial pattern of wetting-drying-wetting from north to south over the EAMR, with an increase of 0.1 to $0.6 \mathrm{~mm} \mathrm{day}^{-1}$ over most of southeastern China and north of $40^{\circ} \mathrm{N}$ and a decrease of 0.1 to $0.5 \mathrm{~mm} \mathrm{day}^{-1}$ over the Yangtze-Huai River valley (Fig. 12a). This is not consistent with that reported by Menon et al. (2002), which indicated that BC forcing primarily contributed to the wetter-south-dryer-north phenomenon in eastern China during the past decades. The change in precipitation caused by $\mathrm{BC}$ forcing is mainly in line with the change in monsoon circulation. The fast and slow responses of precipitation to $\mathrm{BC}$ are almost opposite over the EAMR (Fig. 12b and c) due to the opposite circulation changes. The deep tropospheric warming north of $40^{\circ} \mathrm{N}$ due to the fast response (Fig. 10b) can intensify the vertical ascending motion (Fig. S4b) and moisture transfer, which dominates over the increase in precipitation here. However, the warming in the troposphere and anomalous surface easterly winds between
20 and $30^{\circ} \mathrm{N}$ due to the slow response (Figs. 10c and 11c) are conducive to the development of ascending motion (Fig. S4c) and moisture transport from the oceans, which contributes to the increase in precipitation over these regions. In addition, the southward shifting of the EASJ in the slow response leads to an increase in surface divergence (Fig. 9f) and a decrease in precipitation over the Yangtze-Huai River valley. In general, the spatial distribution of the total precipitation response agrees well with that of the slow precipitation response to BC except north of $40^{\circ} \mathrm{N}$, which also shows the significance of the SST change induced by $\mathrm{BC}$ forcing in impacting the EASM.

\section{Discussion and conclusions}

This study investigates the roles of fast and slow components in shaping the total equilibrium response of the EASM to reflecting $\mathrm{SO}_{4}$ and absorbing BC forcings using an Earth system model with a fully coupled dynamic ocean, in contrast to most of the previous studies that adopted a slab ocean model (e.g., Allen and Sherwood, 2010; Ganguly et al., 2012). Such a decomposition of the total response will be helpful in better understanding the mechanisms by which aerosols impact the EASM. Our results show that reflecting $\mathrm{SO}_{4}$ produces 


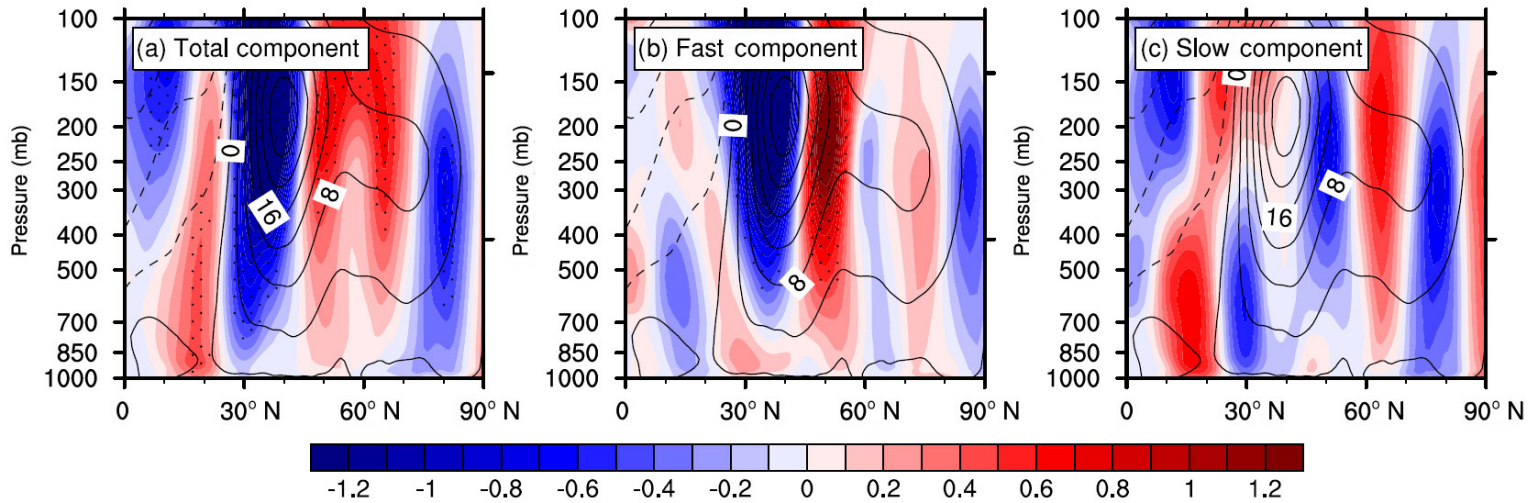

Figure 11. JJA mean total, fast, and slow responses of zonally averaged zonal wind between 100 and $140^{\circ} \mathrm{E}$ to $\mathrm{BC}$ forcing (unit: $\mathrm{m} \mathrm{s}^{-1}$ ). The dashed and solid lines represent the climatological JJA mean easterly and westerly winds in PI, respectively. The dots represent significance at $\geq 95 \%$ confidence level from the $t$ test.

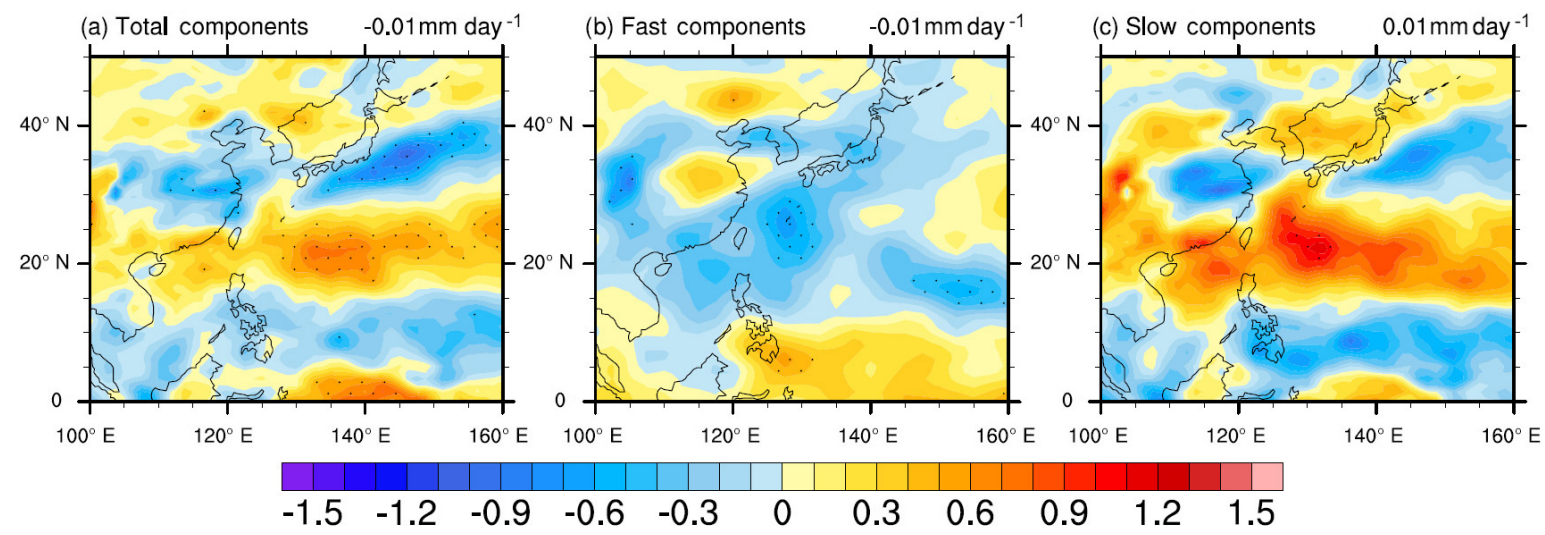

Figure 12. JJA mean total, fast, and slow responses of precipitation rate to $\mathrm{BC}$ forcing (unit: $\mathrm{mm}_{\text {day }}{ }^{-1}$ ). The values in the top right corner of the figures represent the responses averaged over the region $0-50^{\circ} \mathrm{N}, 100-140^{\circ} \mathrm{E}$. The dots represent significance at $\geq 95 \%$ confidence level from the $t$ test.

a global mean ERF of $-0.98 \mathrm{~W} \mathrm{~m}^{-2}$, while absorbing BC leads to an ERF of $+0.36 \mathrm{~W} \mathrm{~m}^{-2}$. Despite the essential difference in forcings, the spatial distribution of the SST response at the global scale is prominently similar between $\mathrm{SO}_{4}$ and $\mathrm{BC}$ forcings. However, a unique characteristic of the SST response to BC is the obvious warming over the Indian Ocean-western Pacific warm pool.

There are significantly different mechanisms between fast and slow responses of the EASM to different aerosol forcings. Table 3 provides a summary of the responses of the EASM in various cases. The $\mathrm{SO}_{4}$-induced fast climate response weakens the EASM through decreasing the landsea surface thermal contrast over the EAMR. This has been shown in many earlier studies (e.g., Jiang et al., 2013; Wang et al., 2015). However, we show here that the $\mathrm{SO}_{4}$-induced SST change (i.e., slow climate response) further weakens the EASM by changing the tropospheric thermodynamic and circulation structures, especially through a southward shifting of the EASJ. Eventually, the EASM circulation is significantly weakened, and the precipitation is reduced over the
EAMR in the total response to $\mathrm{SO}_{4}$. However, the decrease in precipitation over land in East Asia in the total response to $\mathrm{SO}_{4}$ is dominated by the fast response, while the change in precipitation over the adjacent ocean is dominated by the slow response.

The BC-induced changes are weaker and more complicated. The fast climate response significantly strengthens the EASM both by increasing the land-sea surface thermal contrast over the EAMR and moving the EASJ northwards. However, the BC-induced slow climate response weakens the EASM by strongly affecting the atmospheric temperature and circulation. The role of the EASJ has not been clearly shown in previous studies, which often only considered the fast adjustment of climate to $\mathrm{BC}$ forcing. As a result of the competing factors of the land-sea contrast and ESAJ shift, the EASM in the total response to $\mathrm{BC}$ is weaker and less significant, with a slight enhancement north of $30^{\circ} \mathrm{N}$. As for the precipitation responses, the total response to $\mathrm{BC}$ shows a spatial pattern of wetting-drying-wetting from north to south over the EAMR. This differs from the results in Menon et 
al. (2002), which suggested that the increased BC emission contributed to the wetter-south-dryer-north phenomenon in summer over eastern China in the past decades. The spatial pattern of the total precipitation response is similar to that of the slow precipitation response to $\mathrm{BC}$.

This study elaborates on the mechanisms of the impacts of various aerosol species on the EASM system, highlighting the importance of ocean response to aerosol forcings (i.e., slow response component) in driving the changes of the EASM. Given a larger negative ERF due to $\mathrm{SO}_{4}$, it can be speculated that the integrated effect of total anthropogenic aerosols likely tends to weaken the EASM over the industrial era, as suggested by earlier works (e.g., Song et al., 2014; Salzmann et al., 2014).

Our results clearly suggest that one pathway aerosol forcings have to affect the EASM is by changing the land-sea surface thermal contrast, as shown in previous studies (e.g., Liu et al., 2011; Zhang et al., 2012; Salzmann et al., 2014; Wang et al., 2015, 2016). However, we also emphasize the role of the EASJ, which could amplify or offset the effects of the surface thermal contrast. The response of the EASJ to aerosols needs further studies, preferably using multi-model ensembles, because (1) it is quite sensitive to the atmospheric forcing component (Fig. 11b) that is altitude dependent and (2) as a component of the larger NH westerly jet stream, it is more subject to the influence of non-local (outside Asia) aerosols that could undergo a different emission pathway than local aerosol emissions in a shorter time.

Data availability. The model outputs analyzed in this study can be accessed by contacting the corresponding author Lei Lin (linlei3@mail.sysu.edu.cn).

\section{The Supplement related to this article is available online at https://doi.org/10.5194/acp-17-11075-2017- supplement.}

Author contributions. ZW and LL conceived the study and performed the analysis. ZW, LL, MY, and YX wrote the paper. All authors provided comments and contributed to the text.

Competing interests. The authors declare that they have no conflict of interest.

Acknowledgements. The authors thank the two anonymous reviewers for valuable comments and suggestions. This study was supported by the National Key R\&D Program of China (2017YFA0603503 and 2016YFC0203306), (key) National Natural Science Foundation of China (41575139 and 91644211), and Jiangsu Collaborative Innovation Center for Climate Change. 
Edited by: Rolf Müller

Reviewed by: two anonymous referees

\section{References}

Allen, R. J. and Sherwood, S. C.: The impact of natural versus anthropogenic aerosols on atmospheric circulation in the Community Atmosphere Model, Clim. Dynam., 36, 1959-1978, 2010.

Andrews, T., Forster, P. M., Boucher, O., Bellouin, N., and Jones, A.: Precipitation, radiative forcing and global temperature change, Geophys. Res. Lett., 37, L14701, https://doi.org/10.1029/2010GL043991, 2010.

Auffhammer, M., Ramanathan, V., and Vincent, J. R.: Climate change, the monsoon, and rice yield in India, Climatic Change, 111, 411-424, 2012.

Chung, S. H. and Seinfeld, J. H.: Climate response of direct radiative forcing of anthropogenic black carbon, J. Geophys. Res., 110, D11102, https://doi.org/10.1029/2004JD005441, 2005.

Dai, A., Li, H., Sun, Y., Hong, L.-C., Ho, L., Chou, C., and Zhou, T.: The relative roles of upper and lower tropospheric thermal contrasts and tropical influences in driving Asian summer monsoons, J. Geophys. Res.-Atmos., 118, 7024-7045, 2013.

Ding, Y. H. and Chan, J. C. L.: The East Asian summer monsoon: an overview, Meteorol. Atmos. Phys., 89, 117-142, 2005.

Dong, B., Sutton, R. T., Highwood, E. J., and Wilcox, L. J.: Preferred response of the East Asian summer monsoon to local and non-local anthropogenic sulphur dioxide emissions, Clim. Dynam., 46, 1733-1751, 2016.

Forster, P. M., Richardson, T., Maycock, A. C., Smith, C. J., Samset, B. H., Myhre, G., Andrews, T., Pincus, R., and Schulz, M.: Recommendations for diagnosing effective radiative forcing from climate models for CMIP6, J. Geophys. Res.-Atmos., 121, 12460-12475, 2016.

Friedman, A. R., Hwang, Y.-T., Chiang, J. C., and Frierson, D. M.: Interhemispheric temperature asymmetry over the twentieth century and in future projections, J. Climate, 26, 5419-5433, 2013.

Ganguly, D., Rasch, P. J., Wang, H., and Yoon, J.: Fast and slow responses of the South Asian monsoon system to anthropogenic aerosols, Geophys. Res. Lett., 39, L18804, https://doi.org/10.1029/2012GL053043, 2012.

Gettelman, A., Liu, X., Ghan, S. J., Morrison, H., Park, S., Conley, A. J., Klein, S. A., Boyle, J., Mitchell, D. L., and Li, J.-L. F.: Global simulations of ice nucleation and ice supersaturation with an improved cloud scheme in the community atmosphere model, J. Geophys. Res., 115, D18216, https://doi.org/10.1029/2009JD013797, 2010.

Ghan, S. J., Liu, X., Easter, R. C., Zaveri, R., Rasch, P. J., Yoon, J.H., and Eaton, B.: Toward a minimal representation of aerosols in climate models: comparative decomposition of aerosol direct, semi-direct and indirect radiative forcing, J. Climate, 25, 64616476, 2012.

Guo, L., Highwood, E. J., Shaffrey, L. C., and Turner, A. G.: The effect of regional changes in anthropogenic aerosols on rainfall of the East Asian Summer Monsoon, Atmos. Chem. Phys., 13, 1521-1534, https://doi.org/10.5194/acp-13-1521-2013, 2013.

Hong, J. and Kim, J.: Impact of the Asian monsoon climate on ecosystem carbon and water exchanges: a wavelet analysis and its ecosystem modeling implications, Glob. Change Biol., 17, 1900-1916, 2011.

Hsieh, W.-C., Collins, W. D., Liu, Y., Chiang, J. C. H., Shie, C.L., Caldeira, K., and Cao, L.: Climate response due to carbonaceous aerosols and aerosol-induced SST effects in NCAR community atmospheric model CAM3.5, Atmos. Chem. Phys., 13, 7489-7510, https://doi.org/10.5194/acp-13-7489-2013, 2013.

Huang, J., Wang, T., Wang, W., Li, Z., and Yan, H.: Climate effects of dust aerosols over East Asian arid and semiarid regions, J. Geophys. Res.-Atmos., 119, 11398-11416, 2014.

Hurrell, J., Holland, M., Ghan, S., Lamarque, J., Lawrence, D., Lipscomb, W., Mahowald, N., Marsh, D. R. , Neale, R. B., Rasch, P., Vavrus, S., Vertenstein M., Bader D., Collins, W. D., Hack, J. J., Kiehl, J., and Marshall, S.: The Community Earth System Model: a framework for collaborative research, B. Am. Meteorol. Soc., 94, 1339-1360, 2013.

Jiang, Y., Liu, X., Yang, X.-Q., and Wang, M.: A numerical study of the effect of different aerosol types on East Asian summer clouds and precipitation, Atmos. Environ., 70, 51-63, 2013.

Keshavamurty, R. N.: Response of the atmosphere to sea surface temperature anomalies over the equatorial Pacific and the teleconnections of the Southern Oscillation, J. Atmos. Sci., 39, 1241-1259, 1982.

Koch, D. and Del Genio, A. D.: Black carbon semi-direct effects on cloud cover: review and synthesis, Atmos. Chem. Phys., 10, 7685-7696, https://doi.org/10.5194/acp-10-7685-2010, 2010.

Lamarque, J.-F., Bond, T. C., Eyring, V., Granier, C., Heil, A., Klimont, Z., Lee, D., Liousse, C., Mieville, A., Owen, B., Schultz, M. G., Shindell, D., Smith, S. J., Stehfest, E., Van Aardenne, J., Cooper, O. R., Kainuma, M., Mahowald, N., McConnell, J. R., Naik, V., Riahi, K., and van Vuuren, D. P.: Historical (1850-2000) gridded anthropogenic and biomass burning emissions of reactive gases and aerosols: methodology and application, Atmos. Chem. Phys., 10, 7017-7039, https://doi.org/10.5194/acp-10-7017-2010, 2010.

Lei, Y., Hoskins, B., and Slingo, J.: Exploring the interplay between natural decadal variability and anthropogenic climate change in summer rainfall over china. Part I: observational evidence, J. Climate, 24, 4584-4599, 2011.

Li, J., Wu, Z., Jiang, Z., and He, J.: Can global warming strengthen the East Asian summer monsoon?, J. Climate, 23, 6696-6705, 2010.

Li, Z., Lau, W. K.-M., Ramanathan, V., Wu, G., Ding, Y., Manoj, M. G., Liu, J., Qian, Y., Li, J., Zhou, T., Fan, J., Rosenfeld, D., Ming, Y., Wang, Y., Huang, J., Wang, B., Xu, X., Lee, S.-S., Cribb, M., Zhang, F., Yang, X., Zhao, C., Takemura, T., Wang, K., Xia, X., Yin, Y., Zhang, H., Guo, J., Zhai, P. M., Sugimoto, N., Babu, S. S., and Brasseur, G. P.: Aerosol and monsoon climate interactions over Asia, Rev. Geophys., 54, 119-161, 2016.

Lin, L., Gettelman, A., Xu, Y., and Fu, Q.: Simulated responses of terrestrial aridity to black carbon and sulfate aerosols, J. Geophys. Res.-Atmos., 121, 785-794, 2016.

Liu, J., Rühland, K. M., Chen, J., Xu, Y., Chen, S., Chen, Q., Huang, W., Xu, Q., Chen, F., and Smol, J. P.: Aerosol-weakened summer monsoons decrease lake fertilization on the Chinese Loess Plateau, Nat. Clim. Chang., 7, 190-194, 2017.

Liu, X., Xie, X., Yin, Z., Liu, C., and Gettelman, A.: A modeling study of the effects of aerosols on clouds and precipitation over East Asia, Theor. Appl. Climatol., 106, 343-354, 2011. 
Liu, X., Easter, R. C., Ghan, S. J., Zaveri, R., Rasch, P., Shi, X., Lamarque, J.-F., Gettelman, A., Morrison, H., Vitt, F., Conley, A., Park, S., Neale, R., Hannay, C., Ekman, A. M. L., Hess, P., Mahowald, N., Collins, W., Iacono, M. J., Bretherton, C. S., Flanner, M. G., and Mitchell, D.: Toward a minimal representation of aerosols in climate models: description and evaluation in the Community Atmosphere Model CAM5, Geosci. Model Dev., 5, 709-739, https://doi.org/10.5194/gmd-5-709-2012, 2012.

Menon, S., Hansen, J., Nazarenko, L., and Luo, Y. F.: Climate effects of black carbon aerosols in China and India, Science, 297, 2250-2253, 2002.

Ming, Y., Ramaswamy, V., Chen, G.: A model investigation of aerosol-induced changes in boreal winter extratropical circulation, J. Climate, 24, 5125-5133, 2011.

Morrison, H. and Gettelman, A.: A new two-moment bulk stratiform cloud microphysics scheme in the community atmosphere model, version 3 (CAM3). Part I: description and numerical tests, J. Climate, 21, 3642-3659, 2008.

Myhre, G., Shindell, D., Bréon, F.-M., Collins, W., Fuglestvedt, J., Huang, J., Koch, D., Lamarque, J.-F., Lee, D., Mendoza, B., Nakajima, T., Robock, A., Stephens, G., Takemura, T., and Zhang, H.: Anthropogenic and natural radiative forcing, in: Climate Change 2013: The Physical Science Basis. Contribution of Working Group I to the Fifth Assessment Report of the Intergovernmental Panel on Climate Change, edited by: Stocker, T. F., Qin, D., Plattner, G.-K., Tignor, M., Allen, S. K., Boschung, J., Nauels, A., Xia, Y., Bex, V., and Midgley, P. M., Cambridge Univ. Press, Cambridge, UK, New York, NY, USA, 659-740, 2013.

Ocko, I. B., Ramaswamy, V., and Ming, Y.: Contrasting climate responses to the scattering and absorbing features of anthropogenic aerosol forcings, J. Climate, 27, 5329-5345, 2014.

Persad, G. G., Ming, Y., and Ramaswamy, V.: The role of aerosol absorption in driving clear-sky solar dimming over East Asia, J. Geophys. Res.-Atmos., 119, 10410-10424, 2014.

Rotstayn, L. D., Plymin, E. L., Collier, M. A., Boucher, O., Dufresne, J.-L., Luo, J.-J., von Salzen, K., Jeffrey, S. J., Foujols, M.-A., Ming, Y., and Horowitz, L. W.: Declining aerosols in CMIP5 projections: effects on atmospheric temperature structure and midlatitude jets, J. Climate, 27, 6960-6977, 2014.

Salzmann, M., Weser, H., and Cherian, R.: Robust response of Asian summer monsoon to anthropogenic aerosols in CMIP5 models, J. Geophys. Res.-Atmos., 119, 11321-11337, 2014.

Samset, B. H., Myhre, G., Forster, P. M., Hodnebrog, Ø., Andrews, T., Faluvegi, G., Fläschner, D., Kasoar, M., Kharin, V., Kirkevåg, A., Lamarque, J.-F., Olivié, D., Richardson, T., Shindell, D., Shine, K. P., Takemura, T., and Voulgarakis, A.: Fast and slow precipitation responses to individual climate forcers: a PDRMIP multimodel study, Geophys. Res. Lett., 43, 2782-2791, 2016.

Song, F., Zhou, T., and Qian, Y.: Responses of East Asian summer monsoon to natural and anthropogenic forcings in the 17 latest CMIP5 models, Geophys. Res. Lett., 41, 596-603, 2014.

Voigt, A., Pincus, R., Stevens, B., Bony, S., Boucher, O., Bellouin, N., Lewinschal, A., Medeiros, B., Wang, Z., and Zhang, H.: Fast and slow shifts of the zonal-mean intertropical convergence zone in response to an idealized anthropogenic aerosol, J. Adv. Model. Earth Syst., 9, https://doi.org/10.1002/2016MS000902, 2017.
Wang, B., Wu, R., and Lau, K. M.: Interannual variability of Asian summer monsoon: contrast between the Indian and western North Pacific-East Asian monsoons, J. Climate, 14, 40734090, 2001.

Wang, Q. Y., Wang, Z. L., and Zhang, H.: Impact of anthropogenic aerosols from global, East Asian, and non-East Asian sources on East Asian summer monsoon system, Atmos. Res., 183, 224236, 2017.

Wang, T. J., Zhuang, B. L., Li, S., Liu, J., Xie, M., Yin, C. Q., Zhang, Y., Yuan, C., Zhu, J. L., Ji, L. Q., and Han, Y.: The interactions between anthropogenic aerosols and the East Asian summer monsoon using RegCCMS, J. Geophys. Res.-Atmos., 120, 5602-5621, 2015.

Wang, Z. L., Zhang, H., and Zhang, X. Y.: Projected response of East Asian summer monsoon system to future reductions in emissions of anthropogenic aerosols and their precursors, Clim. Dynam., 47, 1455-1468, 2016.

Xu, Y., Bahadur, R., Zhao, C., Leung, L., and Ramanathan, V.: Estimating the radiative forcing of carbonaceous aerosols over California based on satellite and ground observations, J. Geophys. Res.-Atmos., 118, 11148-11160, 2013.

$\mathrm{Xu}$, Y. and Xie, S.-P.: Ocean mediation of tropospheric response to reflecting and absorbing aerosols, Atmos. Chem. Phys., 15, 5827-5833, https://doi.org/10.5194/acp-15-5827-2015, 2015.

$\mathrm{Xu}$, Y., Ramanathan, V., and Washington, W. M.: Observed high-altitude warming and snow cover retreat over Tibet and the Himalayas enhanced by black carbon aerosols, Atmos. Chem. Phys., 16, 1303-1315, https://doi.org/10.5194/acp-161303-2016, 2016.

Yan, H., Qian, Y., Zhao, C., Wang, H., Wang, M., Yang, B., Liu, $\mathrm{X}$., and Fu, Q.: A new approach to modeling aerosol effects on East Asian climate: parametric uncertainties associated with emissions, cloud microphysics, and their interactions, J. Geophys. Res.-Atmos., 120, 8905-8924, 2015.

Yu, R., Wang, B., and Zhou, T.: Tropospheric cooling and summer monsoon weakening trend over East Asia, Geophys. Res. Lett., 31, L22212, https://doi.org/10.1029/2004GL021270, 2004.

Zelinka, M. D., Andrews, T., Forster, P. M., and Taylor, K. E.: Quantifying components of aerosol-cloud-radiation interactions in climate models, J. Geophys. Res.-Atmos., 119, 7599-7615, 2014.

Zhang, H., Wang, Z. L., Guo, P. W., and Wang, Z. Z.: A modeling study of the effects of direct radiative forcing due to carbonaceous aerosol on the climate in East Asia, Adv. Atmos. Sci., 26, 57-66, 2009.

Zhang, H., Wang, Z. L., Wang, Z. Z., Liu, Q. X., Gong, S., Zhang, X.-Y., Shen, Z. P., Lu, P., Wei, X., Che, H., and Li, L.: Simulation of direct radiative forcing of typical aerosols and their effects on global climate using an online AGCM-aerosol coupled model system, Clim. Dynam., 38, 1675-1693, 2012. 